\title{
A clinical study of effects of pregnancy on diseases like painful crisis, seizure disorders, hepatopathy, acute anemia and its outcome
}

\author{
V. Sitalakshmi*, Narmada, Kavitha
}

Department of Obstetrics and Gynecology, Narayana Medical College, Nellore, Tamil Nadu, India

Received: 26 March 2019

Accepted: 19 April 2019

\section{*Correspondence:}

Dr. V. Sitalakshmi,

E-mail: drvsithalakshmi@gmail.com

Copyright: (C) the author(s), publisher and licensee Medip Academy. This is an open-access article distributed under the terms of the Creative Commons Attribution Non-Commercial License, which permits unrestricted non-commercial use, distribution, and reproduction in any medium, provided the original work is properly cited.

\begin{abstract}
Background: The ability of the blood cells to carry oxygen is especially important in pregnancy. Anemia may result in lower amount of oxygen going to the fetus and slowed fetal growth. Because it affects so many organs and body systems, women with the disease are more likely to have complications in pregnancy. The main objective was to study the effects of pregnancy on disease and its outcomes.

Methods: It is a hospital based prospective study. The study was conducted at Narayana Medical College Nellore, Andhra Pradesh. The patients admitted in Obstetrics and Gynecology Department were included in the study. The study included total of 45 patients. Detailed history included age, socioeconomic status, address, education and occupation of the patient's Permission from Institutional Ethics Committee was obtained.

Results: Maximum patients were gravida 2-3, and minimum were gravida 4 or more. Maximum numbers of patients were in group 20-25. The patients with preterm birth that is delivery before 37 weeks of pregnancy were 15 . Low birth weights were 20 and of still birth and new born death was 4 .

Conclusions: The present study was carried out in 45 cases and appropriate prenatal care and careful monitoring throughout pregnancy, can have healthy pregnancy with significant improvement in pregnancy outcome.
\end{abstract}

Keywords: Clinical study, Diseases, Outcome, Pregnant women

\section{INTRODUCTION}

For many years women who suffered from chronic disease were persuaded by their physicians not to pursue becoming pregnant. There are significant fetal and maternal complications in pregnancies experienced by mother. Although advances in medical and obstetrical care have led to an improvement in outcome the complication rate remains significantly increased compared to normal pregnancies.

The ability of the blood cells to carry oxygen is especially important in pregnancy. Anemia may result in lower amount of oxygen going to the fetus and slowed fetal growth. Because it affects so many organs and body systems, women with the disease are more likely to have complications in pregnancy.

Complications and increased risks for mother may include, but are not limited to the followings: Infection including urinary tract and lungs, gall bladder problems including gall stones, heart enlargement and heart failure from anemia, toxemia of pregnancy etc.

An altered immune system added to the renal changes associated with pregnancy make patients with sickle 
hemoglobinopathies more prone to pyelonephritis. In addition, pregnancy causes progesterone induced changes in the gastrointestinal system that predisposes the gravid patient to symptomatic cholelithiasis.

The precise reasons for the high incidence of hypertension in these patients are unclear. Multiple factors such as placental ischemia and endothelial injury have been implicated. ${ }^{1}$

Pregnant women usually have some degree of cardiac dysfunction from ventricular hypertrophy. There is increased preload and decreased after load with a normal ejection fraction and a high cardiac output. Chronic hypertension worsens this. ${ }^{2}$

During pregnancy the basal hemodynamic state characterized by high cardiac output and increases blood volume is augmented. ${ }^{3}$

\section{METHODS}

It is a hospital based prospective study. The study was conducted at Narayana Medical College, Nellore, Andhra Pradesh, India. The study was carried out for a period from November 2013 to November 2014 one. The patients admitted in Obstetrics and Gynecology department were included in the study. The study included total of 45 patients.

Initial examination includes an extensive medical history, the past obstetric history is also important with close scrutiny of prior pregnancies associated with preterm labour and obstetric complications, the presence of medical complications should be identified.

Detailed history included age, socioeconomic status, address, education and occupation of the patient. Baseline investigations were carried out. Obstetric history including gravida, parity, number of preterm labour, number of abortion.

Number of still births, history of caesarean section was taken. General examination of patient was done to note maternal pulse, pallor, edema, signs of dehydration, icterus, blood pressure, respiratory rate, cardiovascular and respiratory system was examined. Investigations include complete blood count and urine test.

\section{Inclusive criteria}

- Patients with chief gynecological complain presenting to gynecology department.

- $\quad$ Patients willing to participate in the study.

\section{Exclusive criteria}

- $\quad$ Patients with any other serious ailments.

- Patients not willing to participate in the study.

\section{Statistical analysis}

The obtained data will be compiled, critically analyzed and interpreted. The data analysis will involve an understanding the study of effects of pregnancy on diseases. Quantitative data will be analyzed through SPSS.

\section{RESULTS}

Table 1 shows distribution of cases according to economic status. The minimum percent for patients who has income between 100-200 that is 8.8 and maximum percent for patients who has income 600 and above that is 15.5 .

Table 1: Distribution of cases according to economic status.

\begin{tabular}{|lll|}
\hline Income per month & $\begin{array}{l}\text { Number of } \\
\text { patients }\end{array}$ & Percentage \\
\hline $100-200$ & 4 & 8.8 \\
\hline $201-300$ & 12 & 26.6 \\
\hline $301-400$ & 9 & 20 \\
\hline $401-500$ & 7 & 15.5 \\
\hline $501-600$ & 6 & 13.3 \\
\hline 600 and Above & 7 & 15.5 \\
\hline
\end{tabular}

Table represents distribution of cases according to age groups. Maximum numbers of patients were in group 20-25. Minimum number of patients in age group below 20 years and 31-35 years.

Table 2: Distribution of cases according to age groups.

\begin{tabular}{|lll|}
\hline Age in years & $\begin{array}{l}\text { Number of } \\
\text { patients }\end{array}$ & Percentage \\
\hline Below 20 years & 1 & 2.2 \\
\hline $20-25$ & 23 & 51.1 \\
\hline $26-30$ & 20 & 44.4 \\
\hline $31-35$ & 1 & 2.2 \\
\hline Above 35 & - & - \\
\hline
\end{tabular}

Table 3 shows distribution of patients according to gravidity. It is obvious from the table that maximum patients were gravida 2-3, and minimum were gravida 4 or more.

Table 3: Distribution of patients according to gravidity.

\begin{tabular}{|lll|}
\hline Gravida & Number of Patients & Percentage \\
\hline 1 & 20 & 44.4 \\
\hline $2-3$ & 22 & 48.8 \\
\hline $4-5$ & 3 & 6.6 \\
\hline
\end{tabular}

Table 4 shows distribution of patients according to Pregnancy diseases in third trimester. 
Table 4: Distribution of patients according to Pregnancy diseases in third trimester.

\begin{tabular}{|lll|}
\hline Pregnancy diseases & $\begin{array}{l}\text { Number of } \\
\text { patients }\end{array}$ & Percentage \\
\hline Painful crisis & 4 & 8.8 \\
\hline Seizure disorders & 9 & 20 \\
\hline Hepatopathy & 3 & 6.6 \\
\hline Acute Anemia & 26 & 57.7 \\
\hline Sickle cell diseases & 2 & 4.4 \\
\hline Acute chest syndrome & 1 & 2.2 \\
\hline
\end{tabular}

\section{Painful crisis}

Vaso - occlusive crises are more common in the latter half of pregnancy during labour and delivery earlier in peuperium when vascular stasis is more likely to occur, and the oxygen demand are increased.

\section{Seizure disorders}

Patients with sickle cell disease have a high frequency of neurological events. A careful history can ferret out the details of a post stroke that left few clinical sequelae by which could predispose the mother to seizures.

\section{Hepatopathy}

Acute and chronic events involving the right upper quadrant have been collectively referred to as sickle hepatopathy.

\section{Acute anemia}

If the patient suddenly develops severe anemia the differential diagnosis includes external blood loss, suppression of bone marrow by infection, inflammation, deficiency of iron, folic acid or B12.

\section{Acute chest syndrome}

This complication usually presents with fever, cough, pleuritic chest pain, pulmonary infiltrates, leukocytosis, and occasionally severe hypoxemia.

Table 5: Complications of pregnancy in third trimester.

\begin{tabular}{|llc|}
\hline $\begin{array}{l}\text { Complications of Pregnancy } \\
\text { in third trimester }\end{array}$ & $\begin{array}{l}\text { No. of } \\
\text { patients }\end{array}$ & $\%$ \\
\hline $\begin{array}{l}\text { Intrauterine growth restriction } \\
\text { (Poor fetal growth) }\end{array}$ & 6 & 13.3 \\
\hline $\begin{array}{l}\text { Preterm birth (before } 37 \\
\text { weeks of pregnancy) }\end{array}$ & 15 & 33.3 \\
\hline $\begin{array}{l}\text { Low birth weight (<5.5 } \\
\text { pounds) }\end{array}$ & 20 & 44.4 \\
\hline Still birth and new born death & 4 & 8.8 \\
\hline
\end{tabular}

Table 5 illustrates Complications of pregnancy in third trimester. The patients with preterm birth that is delivery before 37 weeks of pregnancy were 15 . Low birth weights were 20 and of still birth and new born death was 4 .

\section{DISCUSSION}

Most women tolerate pregnancy without problems, complications such as severe preeclampsia or serious infection may result in ventricular failure. ${ }^{4}$

Eisenstein et al, reported women have an increased incidence of spontaneous abortion (variously reported as $19-28 \%$ ), still births (reports vary between 8 , and 12\%), preterm delivery and neonatal deaths (rates ranging from 3 to $20 \%$ having been reported). ${ }^{5}$

Prophylactic transfusion therapy is a viable option in the treatment of sickle cell disease during pregnancy. If use, however, should be individualized depending on the physician's experience the type of facilities available and the severity of sickle cell disease among women is that region. Because multiple gestations are associated with an increase in the major maternal and fetal complications attributed to vaso-occlusive crisis, prophylactic blood transfusion in these patients is indicated. ${ }^{6}$

Despite recent advances in the management of sickle cell disease, the condition nonetheless frequently causes major morbidity and early death. Consequentially, prevention of the disease through carrier identification, genetic counseling and prenatal diagnosis remain the realistic approach to diminish the impact of the disease and allow better use of available resources for the existing patient populations. , $^{7,8}$

Pregnancies among underweight or overweight women are therefore often regarded as high -risk pregnancies, and thin women are frequently advised to gain weight before becoming pregnant. ${ }^{9,10}$

\section{CONCLUSION}

women experience health problems during pregnancy, this may effect both mother and fetus. Women who were healthy before getting pregnant may get complications during pregnancy.

Therefore, it was felt that if they are given appropriate prenatal care and careful monitoring throughout pregnancy, can have healthy pregnancy with significant improvement in pregnancy outcome.

Funding: No funding sources

Conflict of interest: None declared

Ethical approval: The study was approved by the Institutional Ethics Committee 


\section{REFERENCES}

1. Repke JT. Intrapartum preeclampsia and hypertension in intrapartum obstetrics, Ed repke JT. Churchill Livingston; 1996:404-417.

2. Gandhi SK, Powers JC, Nomeir AM, Fowle K, Kitzman DW, Rankin KM, et al. The pathogenesis of acute pulmonary edema associated with hypertension. N Eng J Med. 2001;344:17.

3. Veille J, Hanson R. Left ventricular systolic and diastolic function is pregnant patients with sickle cell disease. Is J Obtet Crynecol. 1994;170:107.

4. Cunningham FG, Pritchard JA, Hankins GD, Anderson PL, Lucas MJ, Armstrong KF. Peripartum heart failure: idiopathic cardiomyopathy or compounding cardiovascular events?. Obstet Gynecol. 1986 Feb;67(2):157-68.

5. Eisenstein MI, Posner AC, Friedman S. sickle cell anemia in pregnancy. A review of the literature with additional case histories. Amer J Obstet Gynecol. 1956;72(3):622-34.

6. Koshy M, Chisum D, Burd L, Orlina A, How H Management of sickle cell anemia and pregnancy. J Clin Apheresis. 1991;6:230.
7. WHO working group, community control of hereditary anemias bulls WHO. 1983:61:6369.

8. Modell B. APOGI project (Accessible publishing of scientific information): information materials for Hemoglobin disorders. Department of primary care and population sciences university of London; 1998.

9. World Health Organization. Maternal anthropometry for prediction of pregnancy outcomes: memorandum from a USAID/WHO/PAHO Mother Care meeting. Bulletin of the World Health Organization (WHO). 1991;69(5):523-32.

10. Institute of Medicine (US). Subcommittee for a Clinical Application Guide. Nutrition During Pregnancy and Lactation: An Implementation Guide. National Academies; 1992.

Cite this article as: Sitalakshmi V, Narmada, Kavitha. A clinical study of effects of pregnancy on diseases like painful crisis, seizure disorders, hepatopathy, acute anemia and its outcome. Int $\mathbf{J}$ Reprod Contracept Obstet Gynecol 2019;8:1860-3. 